\title{
5.7. СОВРЕМЕННЫЕ НАУЧНЫЕ ВЗГЛЯДЫ НА СУЩНОСТЬ ФИНАНСОВОЙ СИСТЕМЫ
}

Хамалинская В.В., к.э.н., доцент, доцент Департамента общественных финансов Финансового университета при Правительстве РФ, г. Москва;

Хамалинский И.В., к.Т.н., профессор, профессор кафедры государственного и муниципального управления Российской академии народного хозяйства и государственной службы при Президенте РФ (Московский областной филиал)

Актуальность проведенного исследования заключается в необходимости обобщения и систематизации теоретических взглядов и научных методик, определяющих понятие и структуру финансовой системы страны. Авторами показана возможность формирования и использования различных методик исследования закономерностей и особенностей функционирования финансовой системы, что позволит исследовать особенности функционирования финансовой системы и обобщить проблемы и тенденции ее развития.

\section{Литература}

1. Абрамов С.А. К дискуссии о сущности категории «финансы» в российской экономической науке [Текст] / С.А. Абрамов // Современная экономика: проблемы и решения. - 2017. - №12. - С. 8-14.

2. Будович Ю.И. Сущность финансовой системы [Текст] / Ю.И. Будович // Вопросы экономики и права. - 2018. - №6. - С. 54-62.

3. Бырдина К.С. Финансовая система РФ: современное состояние и перспективы развития [Текст] / К.С. Бырдина, В.В. Завгородняя // Инновационная наука. - 2016. - №4-1. - С. 67-72.

4. Дукхани А.Б. Сравнение финансовых систем в США, РФ и ОАЭ [Текст] / А.Б. Дукхани // Вестник УГНТУ. Наука, образование, экономика. Сер. : Экономика. - 2014. - №1. - С. 257-262.

5. Ермолаев Е.А. Теоретические аспекты определения понятия «финансовая система» [Текст] / Е.А. Ермолаев, Ю.С. Завьялов // Деньги и кредит. - 2014. - №7. - С. 63-72.

6. Жеребин В.М. Экономика домашних хозяйств [Текст] : монография / В.М. Жеребин, А.Н. Романов. - М. : ИНФРА-М, 2016. - 232 c.

7. Зайцева О.Д. Современные концепции и теории публичных финансов [Текст] / О.Д. Зайцева, Е.В. Бабина // Экономика и современное право. Научное развитие современного общества : мат-лы Междунар. конф. - 2018. - С. 17-20.

8. Игонина Л.Л. О функциях национальной финансовой системы [Текст] / Л.Л. Игонина // Финансовая аналитика: проблемы и решения. - 2017. - Т. 10 ; №10. - С. 1188-1202.

9. Ишина И.В. Теория и методология изучения финансовой системы [Текст] / И.В. Ишина, В.В. Завгородняя // Аудит и финансовый анализ. - 2016. - №2. - С. 183-188.

10. Каплун А.А. Финансы домашних хозяйств: сущность и роль в развитии инвестиционного потенциала России [Текст] / А.А. Каплун // Вестн. АГТУ ; Сер. : Экономика. - 2015. - №4. - С. 80-91.

11. Лазарова Л.Б. Анализ и оценка современных концепций сущности финансов [Текст] / Л.Б. Лазарова, Ю.Р. Исакова // Экономика и предпринимательство. - 2017. - №4-2. - С. 92-93.

12. Ланкина Ю.С. Сравнительный анализ зарубежных фринансовых систем с фринансовой системой России [Текст] / Ю.С. Ланкина, Л.О. Сердюкова // Социально-гуманитарные и экономические измерения современного общества. Саратов, 2017. - С. 123-128.

13. Матвеева Л.Г. Влияние виртуальной экономики на конкурентоспособность национальной финансовой системы [Текст] / Л.Г. Матвеева, О.А. Чернова // Вестн. Томского гос. ун-та ; Сер. : Экономика. - 2015. - №1. - С. 160-169.

14. Молчанов И.Н. Эволюция научных взглядов на национальную финансовую систему через призму потребностей общества и бизнеса [Текст] / И.Н. Молчанов, Н.П. Молчанова // Экономика. Налоги. Право. - Т. 9 ; №5. - С. 42-49.

15. Смирнов Е.В. и др. Финансовая система государства: значимость и основные фрункции [Текст] / Е.В. Смирнов, В.Н. Никифоров, И.М. Андриенко // Перспективы, и факторы обеспечения устойчивого развития экономики : сб. ст. Междунар. конфр. - 2017. - С. 125-127.

16. Счастная Т.В. Теоретическое осмысление структуры финансовой системы в логике преподавания дисциплины «Финансы» [Текст] / Т.В. Счастная // Проблемы учета и финансов. - 2014. - №4. - С. 72-76.

17. Финансы [Текст] : учеб. / под ред. Е.В. Маркиной. - М. : КНОРУС, 2015. - 432 с.

18. Шевченко Л.М. Факторы, определяющие устойчивость национальной финансовой системы [Текст] / Л.М. Шевченко // Вестн. Саратовского гос. соц.-экон. ун-та. - 2013. - №2. - С. 101-105.

\section{Ключевые слова}

Финансовая система; научные подходы; методика исследования; фуункциональный подход; институциональный подход; фринансы организаций; финансы домашних хозяйств; государственные и муниципальные финансы; сферы фринансовой системы; звенья финансовой системы.

\section{Хамалинская Виктория Владимировна}

Хамалинский Иван Владимирович

\section{РЕЦЕНЗИЯ}

Актуальность темы статьи обусловлена необходимостью теоретического исследования сущности, состава фринансовой системы с целью определения отдельных сфер и звеньев финансовой системы, для дальнейшего анализа тенденций и показателей развития данных сфер и звеньев национальной финансовой системы. 
Научная новизна и практическая значимость. Авторами осуществлен анализ и систематизация научных взглядов отечественных и зарубежных авторов, исследовавших сущность и состав финансовой системы. Показаны общие и отличительные особенности определения состава финансовой системы в рамках разных научных теорий, подходов и концепций. Отражены особенности научных взглядов зарубежных авторов.

Обобщены научные взгляды отечественных авторов, рассматривающих состав финансовой системы, ее функции, а также фракторы, влияющих на формирование финансовой системы. Выражено авторское мнение о составе финансовой системы в рамках функционального подхода. Подробно рассмотрены сферы и звенья финансовой системы в рамках данного научного подхода, раскрыта роль субъектов финансовых отношений, осуществляемых в финансовой системе.

Исследование проведено авторами путем обобщения теоретических положений научных трудов отечественных и зарубежных исследователей. Стиль и логика изложения материала соответствуют научному характеру статьи.

В качестве замечаний можно отметить следующее: авторы говорят о дополнении функций финансовой системы, но в табл. 2 их так и не приводят; непонятно почему среди звеньев финансовой системы отсутствуют финансы домашних хозяйств (рис. 3).

Учитывая все вышеизложенное, рекомендую статью к.э.н., доцента В.В. Хамалинской и к.Т.н., профессора И.В. Хамалинского «Современные научные взгляды на сущность финансовой системы» к публикации.

Макашина О.В., Ә.э.н, профессор, профессор Департамента общественных фринансов ФГОБУ ВО «Финансовый университет при Правительстве РФ», г. Москва.

DOI 10.38097/AFA.2020.94.72.016 